\title{
KAPASITAS ADAPTIF DESAIN SISTEM PEMILIHAN UMUM TERHADAP SITUASI PANDEMI; STUDI KASUS PELAKSANAAN PILKADA SERENTAK 2020
}

\author{
Yusa' Farchan \\ Program Studi Ilmu Pemerintahan Universitas Sutomo \\ email:yusak1982@gmail.com
}

Paper Accepted: 27 September 2021
Paper Reviewed: 06-12 Oktober 2021
Paper Edited: 13-19 Oktober 2021
Paper Approved: 20 Oktober 2021

\begin{abstract}
ABSTRAK
Meskipun pilkada serentak 2020 dianggap sebagai success story dan role model penyelenggaraan pilkada di tengah situasi pandemi covid-19, namun pilkada serentak 2020 tetap menyimpan berbagai persoalan krusial, terutama dari sisi basis legal atau pengaturan pilkada. Penelitian ini dilakukan untuk menjawab dua pertanyaan penting yaitu; pertama, bagaimana kapasitas adaptif desain sistem pemilihan umum (pilkada) terhadap situasi pandemi?; kedua, bagaimana evaluasi pelaksanaan pilkada serentak 2020 di tengah pandemi covid-19?. Penelitian ini menggunakan metode kualitatif dengan pendekatan studi kasus. Analisis data dilakukan dengan pendekatan analisis deskriptif. Dari hasil penelitian ditemukan beberapa hal. Pertama, UU dan berbagai peraturan pilkada sebelum datangnya pandemi covid-19 di Indonesia, awal Maret 2020, belum memadai karena tidak menyediakan ruang pengaturan yang cukup terhadap situasi bencana non alam. Dengan kata lain, desain sistem pemilihan umum (pilkada) tidak memiliki kapasistas adaptif terhadap situasi bencana non alam. Kedua, meskipun secara umum pelaksanaan pilkada serentak 2020 berlangsung aman dan terkendali, namun terdapat sejumlah masalah antara lain: pelanggaran protokol kesehatan covid-19 di beberapa daerah; daftar pemilih tetap (DPT) yang tidak ditempel; keterbatasan jaringan dalam penghitungan suara melalui Sirekap; dan hambatan cuaca. Ketiga, pilkada 2020 lebih merefleksikan kehendak kepentingan elite dari pada kepentingan publik secara luas. Keempat, pilkada di era pandemi membentuk standar cost politik dengan mengacu pada program sembako dalam praktek vote buying antara kandidat dengan pemilih. Kelima; penggunaan perangkat teknologi informasi yang belum optimal terutama bagi kandidat. Keenam, jaminan kesehatan dan perlindungan hak pilih yang belum optimal.
\end{abstract}

Kata Kunci : kapasitas adaptif; sistem pilkada; pandemi covid-19 


\section{PENDAHULUAN}

\section{Latar Belakang}

Perpu Nomor 2 Tahun 2020 Tentang Perubahan Ketiga Atas UU Nomor 1 Tahun 2015 Tentang Penetapan Perpu Nomor 1 Tahun 2014 Tentang Pemilihan Gubernur, Bupati, dan Walikota Menjadi UU menunda pelaksanaan pemungutan suara pilkada dari September ke Desember 2020. Dengan demikian, pilkada dilangsungkan ditengah pandemi covid-19.

Dalam Peraturan KPU Nomor 6 Tahun 2020 Tentang Pelaksanaan Pemilihan Gubernur Dan Wakil Gubernur, Bupati dan Wakil Bupati, dan/atau Wali Kota dan Wakil Wali Kota Serentak Lanjutan Dalam Kondisi Bencana Nonalam Corona Virus Disease 2019 (Covid-19), KPU memastikan sembilan tahapan Pemilihan 2020 dilaksanakan dengan menerapkan protokol kesehatan secara ketat. Sembilan tahapan itu mulai dari pembentukan dan tata kerja PPK, PPS, KPPS, dan PPDP; pemutakhiran data dan penyusunan daftar pemilih; pencalonan; pelaksanaan kampanye; laporan dan dana kampanye; pemungutan dan penghitungan suara; rekapitulasi hasil pengitungan suara dan penetapan hasil pemilihan; sosialisasi, pendidikan pemilih, dan partisipasi masyarakat; dan pengamanan perlengkapan pemilihan.

Protokol kesehatan yang dimaksud meliputi pelaksanaan rapid test bagi Penyelenggara, penggunaan Alat Pelindung Diri (APD) bagi Penyelenggara, penyediaan sarana sanitasi, pengecekan suhu tubuh, pengaturan jaga jarak, pengaturan larangan berkerumun, pembatasan jumlah peserta di setiap tahapan, pelibatan tim kesehatan atau Gugus Tugas Percepatan Penanganan Covid-19 serta pemanfaatan media daring untuk menggantikan pertemuan.

Dalam situasi normal, penyelenggaraan pilkada sejauh ini masih diwarnai dengan berbagai persoalan krusial antara lain daftar pemilih, kampanye, politik uang hingga tingkat partisipasi pemilih. Dengan tidak meragukan kapasitas penyelenggara pemilihan, pelaksanaan pilkada di tengah grafik covid19 yang belum melandai Desember 2020 lalu, dikhawatirkan menimbulkan persoalan-persoalan baru, yang secara umum akan berimbas pada kualitas pilkada yang buruk. Apalagi, dukungan anggaran dari pemerintah juga tampak tersendat sebagai konsekuensi sempitnya ruang fiskal.

Meskipun sejumlah kalangan terutama pemerintah dan DPR RI menganggap bahwa pilkada serentak 2020 telah menjadi success story Indonesia yang bisa menjadi role model penyelenggaraan pilkada di tengah situasi pandemi, namun pilkada serentak 2020 tetap menyimpan berbagai persoalan krusial yang harus dituntaskan, terutama dari sisi basis legal atau pengaturan pilkada yang belum adaptable dengan segala kemungkinan situasi yang terjadi seperti pandemi covid-19.

\section{Pertanyaan Penelitian}

Penelitian ini dilakukan untuk menjawab dua masalah pokok yaitu;

1) Bagaimana kapasitas adaptif desain sistem pemilihan umum (pilkada) terhadap situasi pandemi? Dengan kata lain, apakah basis legal pegaturan pilkada adaptable terhadap situasi bencana khususnya bencana non alam (covid-19)?

2) Bagaimana evaluasi pelaksanaan pilkada serentak 2020 di tengah pandemi covid-19?

\section{METODE PENELITIAN}

Penelitian ini menggunakan metode kualitatif dengan pendekatan studi kasus. Studi kasus yang diangkat adalah pilkada serentak tahun 2020. Analisis data dilakukan dengan pendekatan analisis deskriptif.

\section{LANDASAN TEORI}

Desain Sistem Pemilihan Umum

Desain sistem pemilu dalam konteks kajian ini lebih difokuskan pada konsepsi bahwa pilkada adalah bagian dari pemilihan umum. Salah satu argumentasi 
mengapa Undang-Undang Pemilihan Kepala Daerah dibuat secara terpisah dari Undang-Undang Pemilu adalah karena pemilihan kepala daerah dianggap bukan pemilu. Pemahaman ini seolah-olah diperkuat oleh Putusan MK No 97/PUUXI/2013 tertanggal 19 Mei 2014, yang menolak mengadili penyelesaian perselisihan hasil pemilihan kepala daerah. Padahal, putusan MK tersebut dikeluarkan lebih karena MK tidak ingin waktu dan energinya habis untuk menyelesaikan perselisihan hasil pilkada karena pemilihan kepala daerah digelar sepanjang tahun. Jika itu masalahnya, mengubah jadwal pemilihan kepala daerah menjadi solusi. Itulah sebabnya, ketika UU No 8/2015 meminta MK untuk tetap mengadili perselisihan hasil pemilihan kepala daerah (yang sudah diserentakkan), MK bersedia menerimanya.

Melalui Putusan Mahkamah Konstitusi No 72-73/PUU-II 2004 tertanggal 22 Maret 2005, sesungguhnya MK sudah menetapkan bahwa pemilihan kepala daerah adalah pemilu. Oleh karenanya, MK kemudian menggunakan istilah pemilihan umum kepala daerah atau pemilukada, dan kemudian diakomodasi dalam UU No 12/2008. Penafsiran secara historis dan sistematis terhadap naskah UUD 1945 juga memastikan bahwa pilkada adalah pemilu.

Perubahan Kedua UUD 1945, Pasal 18 ayat (4) menyatakan, "Gubernur, Bupati, dan Walikota masing-masing sebagai kepala pemerintahan daerah propinsi, kabupaten, dan kota dipilih secara demokratis." Perumusan frasa "dipilih secara demokratis" dilakukan dengan pertimbangan, bahwa kepala daerah dipilih melalui pemilu atau tidak, tergantung pada bagaimana presiden dipilih. Sejarah lalu mencatat, dalam Perubahan Ketiga UUD 1945, Pasal 6A ayat (1) menyatakan, "Presiden dan Wakil Presiden dipilih dalam satu pasangan secara langsung oleh rakyat." Dengan demikian, frasa "dipilih secara demokratis" harus ditafsirkan dipilih langsung oleh rakyat. Dipilih langsung oleh rakyat berarti, baik presiden maupun kepala daerah, dipilih melalui pemilihan umum.

Sementara itu, pendapat lain mengatakan bahwa pemilihan kepala daerah adalah rezim otonomi daerah karena diatur di dalam UUD 1945 Bab VI Pemerintahan Daerah. Hal ini berbeda dengan rezim pemilu yang diatur dalam UUD 1945 Bab VIIB tentang Pemilihan Umum sehingga pemilihan kepala daerah dalam konteks ini dimaknai bukan sebagai pemilu. Perdebatan rezim otonomi versus rezim pemilu berdasarkan pengaturan dalam konstitusi tersebut sesungguhnya tidak relevan karena DPRD yang merupakan perangkat otonomi daerah tidak hanya diatur dalam Bab VI Pemerintahan Daerah, tetapi juga diatur dalam Bab VIIB Pemilihan Umum. Oleh karena itu, penafsiran bahwa pemilihan kepala daerah bukan pemilu sulit dipertanggungjawabkan dan tidak mendapatkan legitimasi atas praktik pilkada yang terjadi dalam sistem politik Indonesia.

Dalam praktiknya, penyelenggaraan pemilihan kepala daerah secara langsung oleh rakyat sesungguhnya tidak berbeda dengan pemilu legislatif maupun pemilu presiden. Kesamaan tersebut dapat terlihat dari: pertama, asas yang digunakan: langsung, umum, bebas, rahasia, jujur dan adil (luber dan jurdil); kedua, para aktor yang teribat yaitu penyelenggara (KPU), pemilih, partai politik, dan calon; ketiga, manajemen atau tahapan yang digunakan mencakup pendaftaran pemilih, pendaftaran calon, kampanye, pemungutan dan penghitungan suara, penetapan hasil, dan pelantikan, dan; keempat, model penegakan hukum yang digunakan, mencakup penanganan pelanggaran kode etik, pelanggaran administrasi, dan tindak pidana, serta penyelesaian perselisihan administrasi dan perselisihan hasil.

Oleh karena itu jika pengaturan dan penyelenggaraan pemilihan kepala daerah diintegrasikan dengan pemilu legislatif dan pemilu presiden, maka sebetulnya dampaknya akan signifikan terhadap upaya pembangunan demokrasi politik.

\section{Desain Sistem Pilkada Langsung}

Untuk menjamin Pemilihan Gubernur, Bupati, dan Walikota dilaksanakan secara demokratis sebagaimana diamanatkan dalam Pasal 18 
ayat (4) Undang-Undang Dasar Negara Republik Indonesia Tahun 1945 maka kedaulatan rakyat serta demokrasi dari rakyat, oleh rakyat, dan untuk rakyat wajib dihormati sebagai syarat utama pelaksanaan Pemilihan Gubernur, Bupati, dan Walikota.

Kedaulatan rakyat dan demokrasi tersebut perlu ditegaskan dengan pelaksanaan Pemilihan Gubernur, Bupati, dan Walikota secara langsung oleh rakyat, dengan melakukan beberapa perbaikan mendasar atas berbagai permasalahan pemilihan langsung yang selama ini telah dilaksanakan. Pembentukan UndangUndang Nomor 22 Tahun 2014 tentang Pemilihan Gubernur, Bupati, dan Walikota yang mengatur mekanisme pemilihan kepala daerah secara tidak langsung melalui Dewan Perwakilan Rakyat Daerah telah mendapatkan penolakan yang luas oleh rakyat dan proses pengambilan keputusannya tidak mencerminkan prinsip demokrasi.

Selain berdasarkan alasan tersebut di atas, terdapat pertimbangan mengenai kegentingan yang memaksa sesuai dengan Putusan Mahkamah Konstitusi Nomor 138/PUU-VII/2009 yang di dalamnya memuat tentang persyaratan perlunya Peraturan Pemerintah Pengganti UndangUndang apabila:

1) adanya keadaan yaitu kebutuhan mendesak untuk menyelesaikan masalah hukum secara cepat berdasarkan Undang-Undang;

2) Undang-Undang yang dibutuhkan tersebut belum ada sehingga terjadi kekosongan hukum atau ada Undang-Undang tetapi tidak memadai;

3) kekosongan hukum tersebut tidak dapat diatasi dengan cara membuat Undang-Undang secara prosedur biasa karena akan memerlukan waktu yang cukup lama sedangkan keadaan yang mendesak tersebut perlu kepastian untuk diselesaikan.

Atas dasar tersebut, maka perlu menetapkan Peraturan Pemerintah
Pengganti Undang-Undang tentang Pemilihan Gubernur, Bupati, dan Walikota.

Desain pilkada langsung saat ini merupakan kelanjutan dari pilkada langsung yang telah dilaksanakan sejak gelombang pertama pilkada tahun 20052010, dilanjutkan gelombang kedua 20102015, dan gelombang ketiga 2015-2020.

Didasari oleh semangat perubahan secara menyeluruh terhadap sistem pemilihan umum, maka pemilihan kepala daerah juga dilakukan dengan mekanisme pemilihan langsung. Pada Juni 2005, Pilkada langsung pertama kali digelar di Kabupaten Kutai Kartanegara, Kalimantan Timur.

\section{Kondisi Pandemi}

World Health Organization (WHO) telah menyatakan COVID-19 sebagai Global Pandemic pada tanggal 11 Maret 2020. Sementara itu, pemerintah Indonesia telah menyatakan bahwa bencana non alam yang diakibatkan oleh penyebaran Corona Virus Disease 2019 (Covid-19) merupakan bencana nasional melalui Keputusan Presiden No 12 Tahun 2020 Tentang Penetapan Bencana Non Alam Penyebaran Corona Virus Desease 2019 (Covide-19) Sebagai Bencana Nasional. Diktum Kesatu Keppres No 12 Tahun 2020 menetapkan bencana nonalam yang diakibatkan oleh penyebaran Corona Virus Disease 2019 (COVID-19/ sebagai bencana nasional

Untuk mengakomodir pandemi covid-19 yang dinyatakan sebagai bencana non alam oleh pemerintah, maka dalam konteks payung hukum pelaksanaan pilkada, juga dilakukan penyesuaian dengan melakukan perubahan atas ketentuan dalam Perpu No.1 Tahun 2014 Tentang Pemilihan Gubernur, Bupati, dan Walikota yang telah ditetapkan sebagai UU melalui UU No. 1 tahun 2015.

Salah satu ketentuan dalam Perpu No.1 Tahun 2014 yang diubah dengan Perpu No.2 Tahun 2020 Tentang Perubahan Ketiga Atas UU Nomor 1 Tahun 2015 adalah Pasal 120 yang bunyinya menjadi "(1) Dalam hal pada sebagian wilayah Pemiliban, selurub wilayah Pemilihan, sebagian 
besar daerah, atau seluruh daerah terjadi kerusuban, gangguan keamanan, bencana alam, bencana nonalam, atau gangguan lainnya yang mengakibatkan sebagian tahapan penyelenggaraan Pemiliban atau Pemiliban serentak tidak dapat dilaksanakan, dilakukan Pemiliban lanjutan atau Pemiliban serentak lanjutan”.

Perubahan yang terjadi dalam ketentuan Pasal 120 tersebut adalah dengan menambahkan satu frasa yaitu bencana non alam. Hal ini ditambahkan untuk mengakomodir pandemi covid-19 yang dinyatakan sebagai bencana non alam oleh pemerintah melalui Keputusan Presiden No 12 Tahun 2020 Tentang Penetapan Bencana Non Alam Penyebaran Corona Virus Desease 2019 (Covide-19) Sebagai Bencana Nasional. Atas dasar ini juga pemerintah memundurkan jadwal pelaksanaan pilkada, dari September 2020 ke Desember 2020.

\section{Kapasitas Adaptif}

Kapasitas adaptif adalah kemampuan sistem sosial secara sosial ekologi untuk tetap siap dan tegap dalam menghadapi goncangan dan merespon perubahan dari faktor internal dan eksternal (Armitage dan Plummer 2010:1). Kemampuan adaptif juga dilihat sebagai daya lenting, stabilitas, dan fleksibilitas ketahanan sistem sosial dari ancaman atau bahaya yang dapat menyesuaikan diri dengan lingkungan (Smit dan Wandel 2006).

Proses pengembangkan kapasitas adaptif tersebut juga ditentukan melalui penggunaan sumber daya atau potensi serta modifikasi sistem kelembagaan dan aturan atau norma (Pelling dan High 2005).

Terminologi kapasitas adaptif digunakan dalam kajian ini untuk mengukur sejauh mana suatu sistem politik memiliki daya lenting dalam menghadapi perubahan atau suatu goncangan tertentu. Dalam konteks ini, bagaimana suatu perangkat hukum, kelembagaan dan aturan tentang pemilihan umum kepala daerah memiliki kapasitas adaptif terhadap situasi pandemi atau bencana non alam yang telah menimbulkan dampak signifikan di berbagai dimensi kehidupan.

\section{HASIL DAN PEMBAHASAN}

\section{Desain Sistem Pilkada Langsung Serentak}

Untuk menjawab kapasitas adaptif desain sistem pemilihan umum (pilkada) terhadap situasi pandemi, maka terlebih dulu diuraikan perkembangan sistem dan pelaksanaan pilkada di Indonesia.

Sejauh ini, mekanisme pengisian jabatan kepala daerah di Indonesia pernah mengikuti berbagai sistem sejak kemerdekaan. Dalam konteks ini, setidaknya terdapat empat sistem pemilihan kepala daerah yang pernah digunakan di Indonesia sebelum pemilihan langsung (Saraswati 2011).

Pertama, sistem penunjukan atau pengangkatan oleh pusat. Sistem ini sudah digunakan sejak masa Pemerintahan Kolonial Hindia Belanda, penjajahan Jepang, serta setelah kemerdekaan. Setelah kemerdekaan, pemerintah menggunakan sistem ini berdasarkan UU 1/1945, UU 22/1948, dan UU 1/1957.

Kedua, sistem penunjukan. Sistem ini digunakan berdasarkan Penetapan Presiden 6/1959 jo Penetapan Presiden 5/1960, UU 6/1956, dan UU 18/1956, atau yang dikenal dengan era Dekrit Presiden. Selain itu, sistem ini juga diberlakukan berdasarkan Penetapan Presiden 6/1959 jo Penetapan Presiden $5 / 1960$ disertai alasan "situasi yang memaksa".

Ketiga, sistem pemilihan perwakilan. Sistem ini merupakan perwujudan UU 5/1974. Dengan sistem ini, pemilihan kepala daerah dilakukan oleh lembaga DPRD. Selanjutnya, presiden akan menentukan calon kepala daerah terpilih.

Keempat, sistem pemilihan perwakilan (murni). Sistem ini mendasarkan pelaksanaannya pada UU 18/1965 dan UU 22/1999. Dengan sistem ini, kepala daerah dipilih secara murni oleh lembaga DPRD tanpa intervensi pemerintah pusat.

Selanjutnya, sejak 2005, pemilihan kepala daerah dilakukan secara langsung berdasarkan UU 32/2004 tentang Pemerintahan Daerah. Dasar hukum penyelenggaraan pilkada periode 2005- 
2008 menggunakan undang-undang tersebut yang kemudian mengalami dua kali perubahan.

Perubahan pertama melalui UU 8/2005 tentang Penetapan Peraturan Pemerintah Pengganti Undang-Undang Nomor 3 Tahun 2005 menjadi UndangUndang. Perubahan kedua melalui UU 12/2008 tentang Perubahan Kedua Atas Undang-Undang Nomor 32 Tahun 2004 tentang Pemerintahan Daerah.

Dalam UU 32/2004, disebutkan bahwa partai politik merupakan satusatunya institusi yang bisa mengajukan pasangan calon peserta pemilihan kepala daerah. Hal itu menunjukkan pilkada yang dilangsungkan pada periode 2005-2008 merupakan arena politik yang dimiliki partai politik.

Dengan kata lain, partai politik memiliki posisi kuat dalam hal pengajuan pasangan calon peserta pilkada dibandingkan dengan institusi atau lembaga lain, misalnya organisasi kemasyarakatan, asosiasi, maupun lembaga berbadan hukum. Hanya melalui pintu partai politiklah seseorang atau kandidat bisa memiliki kesempatan untuk berkompetisi menjadi calon pemimpin di daerah.

Akan tetapi, berdasarkan UU 12/2008, sumber calon kepala daerah maupun wakilnya tak lagi hanya berasal dari partai politik, tetapi juga dari calon perseorangan. Munculnya kesempatan bagi calon perseorangan berawal dari Putusan Mahkamah Konstitusi Nomor 5/PUUV/2007 tanggal 23 Juli 2007 tentang Calon Perseorangan. Putusan MK tersebut lantas ditindaklanjuti dengan pembentukan UU 12/2008. Dengan terbitnya UU 12/2008, terbuka kesempatan bagi calon kepala daerah untuk maju dalam pemilihan tanpa harus melalui pengajuan dari partai politik.

Pada perkembangan berikutnya, seiring dengan makin maraknya penyelenggaraan pilkada di berbagai daerah, pada era Presiden Susilo Bambang Yudhoyono, pemerintah menerbitkan UU 22/2014 tentang Pemilihan Gubernur, Bupati, dan Walikota. UU tersebut disahkan dan ditandatangani Presiden
Susilo Bambang Yudhoyono di pengujung masa tugasnya sebagai presiden pada 30 September 2014.

Undang-Undang

tersebut mengembalikan mekanisme pemilihan kepala daerah kepada DPRD. Namun, UU 22/2014 mendapatkan penolakan yang luas oleh rakyat. Oleh karena itu, pada 2015 di era pemerintahan Presiden Joko Widodo, pemerintah menerbitkan UU 1/2015 tentang Penetapan Peraturan Pemerintah Pengganti Undang-Undang Nomor 1 Tahun 2014 Menjadi UndangUndang.

Dengan UU tersebut, kepala daerah kembali dipilih secara langsung oleh rakyat. Regulasi ini juga menandai era pilkada serentak. Beberapa tahun sebelumnya, pilkada dilaksanakan pada tahun yang sama, tetapi pelaksanaannya belum tentu pada bulan dan tanggal yang sama.

Sesuai dengan dinamika perkembangan politik, UU 1/2015 mengalami empat kali perubahan. Perubahan pertama melalui UU 8/2015 tentang Perubahan atas UU 1/2015. Perubahan kedua terjadi melalui UU 10/2016 tentang Perubahan Kedua Atas UU 1/2015. Perubahan ketiga dilakukan melalui Perppu 2/2020 tentang Perubahan Ketiga atas UU 1/2015. Perppu 2/2020 ditandatangani Presiden Joko Widodo pada 4 Mei 2020. Produk hukum ini mengatur perlunya penundaan pelaksanaan pilkada serentak di tengah pandemi. Perubahan keempat terjadi melalui UU 6/2020 tentang Penetapan Perppu 2/2020 Menjadi Undang-Undang.

Dengan demikian, UU 6/2010 merupakan aturan terbaru sebagai dasar penyelenggaraan pilkada serentak di tengah pandemi Covid-19. Undang-Undang ini ditandatangani Presiden Joko Widodo pada tanggal 11 Agustus 2020 tanpa banyak mengubah ketentuan syarat pencalonan kepala daerah sebagaimana tercantum dalam UU 10/2016. Teknis tahapan dan pelaksanaan pilkada di tengah pandemi selanjutnya dituangkan dalam peraturan KPU.

Semula, Pilkada Serentak 2020 akan dilaksanakan pada tanggal 23 September 
2020. Akan tetapi, karena pandemi virus korona belum mereda, pelaksanaan pilkada dilaksanakan pada 9 Desember 2020. Pilkada Serentak 2020 dilaksanakan di 270 daerah, dengan perincian 9 provinsi, 224 kabupaten, dan 37 kota.

\section{Kapasitas Adaptif Desain Sistem Pemilihan Umum (Pilkada) Terhadap Situasi Pandemi}

Sebelum terbitnya Perpu No.2 Tahun 2020, payung hukum pilkada menggunakan UU No 1 Tahun 2015 Tentang Penetapan Perpu Nomor 1 Tahun 2014 Tentang Pemilihan Gubernur, Bupati, Dan Walikota Menjadi UndangUndang. Dalam UU No 1 Tahun 2015 tersebut, meskipun keadaan bencana telah dicantumkan dalam pasal 120 dan pasal 121, tetapi nomenklatur bencana tersebut hanya mencakup bencana alam. Pasal 120 menyatakan sebagai berikut:

1) Dalam hal sebagian atau seluruh wilayah Pemilihan terjadi kerusuhan, gangguan keamanan, bencana alam, atau gangguan lainnya yang mengakibatkan sebagian tahapan penyelenggaraan Pemilihan tidak dapat dilaksanakan maka dilakukan Pemilihan lanjutan.

2) Pelaksanaan Pemilihan lanjutan dimulai dari tahap penyelenggaraan Pemilihan yang terhenti.

Sementara itu, Pasal 121 menyatakan;

1) Dalam hal di suatu wilayah Pemilihan terjadi bencana alam, kerusuhan, gangguan keamanan, dan/atau gangguan lainnya yang mengakibatkan terganggunya seluruh tahapan penyelenggaraan Pemilihan maka dilakukan Pemilihan susulan.

2) Pelaksanaan Pemilihan susulan dilakukan untuk seluruh tahapan penyelenggaraan Pemilihan.

Kalusul yang tertulis dalam Pasal 120 dan Pasal 121 UU No 1 Tahun 2015 tersebut tidak memberi ruang pengaturan yang tegas dan detail apabila terjadi gangguan bencana non alam. Sementara itu, pada awal Maret 2020, Indonesia dikagetkan dengan datangnya pandemi covid-19 yang sebelumnya telah melanda beberapa negara lain sehingga mengakibatkan terjadinya perubahan besar perilaku organisasi di berbagai sektor kehidupan, termasuk politik dan pemerintahan.

Dengan demikian, desain sistem pemilihan umum (pilkada) yang dimiliki, dapat dikatakan tidak memiliki kapasistas adaptif terhadap situasi bencana seperti pandemi covid-19. Pada titik ini, dapat disimpulkan bahwa UU dan berbagai peraturan tentang pilkada belum memadai karena tidak menyediakan ruang pengaturan yang cukup terhadap berbagai situasi yang potensial terjadi dalam kehidupan masyarakat seperti bencana non alam (pandemi covid-19).

Meskipun sudah mengalami pergantian sistem pemilihan selama lima kali, tetapi berbagai peraturan pilkada yang ada tetap belum menyediakan ruang yang cukup untuk menjawab segala kemungkinan yang terjadi. Kondisi inilah yang memaksa stakeholder terkait khususnya pemerintah dan DPR RI bergerak cepat untuk mengakselerasikan berbagai peraturan yang ada dalam menyikapi pandemi covid yang datang secara bersamaan dalam periode tahun pilkada.

Oleh karena itulah, untuk menjaga kelangsungan proses demokrasi lokal dan kedaulatan rakyat, pemerintah mengambil terobosan hukum dengan mengeluarkan Perpu No.2 Tahun 2020 tentang Perubahan Ketiga atas UU 1 No. 2015 yang ditandatangani Presiden Joko Widodo pada 4 Mei 2020. Produk hukum inilah yang mengatur perlunya penundaan pelaksanaan pilkada serentak di tengah pandemi. Perpu No.2 Tahun 2020 kini telah ditetapkan menjadi UU melalui UU $6 / 2020$

\section{Evalusasi Pilkada Serentak 2020}

Meskipun secara umum pelaksanaan pilkada serentak 2020 telah berlangsung aman dan terkendali, namun terdapat sejumlah catatan sebagai berikut:

Pertama, dari sisi implementasi protokol kesehatan (prokes) pencegahan penyebaran covid-19, masih ditemukan 
berbagai pelanggaran di beberapa daerah. Bentuk-bentuk pelanggaran mencakup; tidak digunakannya masker dan APD oleh penyelenggara pemilu pada saat bertugas; lokasi TPS tidak di ruang terbuka; hadirnya penyelenggara pemilu terkonfirmasi positif covid ke TPS; tidak ditaatinya jaga jarak; dan tidak tersedianya fasilitas cuci tangan di beberapa TPS. Meski demikian, secara umum, sosialisasi massif dari penyelenggara pilkada dan pemerintah mengenai penerapan prokes mampu berdampak kepada kesadaran pemilih yang cukup baik.

Kedua, dari aspek penyelenggaraan, masih terdapat sejumlah masalah terkait daftar pemilih tetap (DPT) yang tidak ditempel atau perlakuan petugas yang berbeda terhadap kasus yang sama. Kondisi ini menggambarkan bahwa tingkat pemahaman dan kemandirian penyelenggara pemilihan di setiap daerah berpengaruh langsung terhadap kualitas pelaksanaan pemungutan dan penghitungan suara.

Ketiga, dari sisi penggunaan sistem informasi. Jika KPU menggunakan Sirekap (Sistem Informasi Rekapitulasi), maka Bawaslu menggunakan Siwaslu. Dalam mendokumentasikan hasil penghitungan suara, Sirekap dan Siwaslu menggunakan metode yang hampir sama yaitu memfoto C.Hasil-KWK dan mengirimkannya melalui aplikasi Android. Selain mendokumentasikan hasil, Siwaslu juga mendokumentasikan proses persiapan pelaksanaan pemungutan dari masa tenang, persiapan logistik pemungutan suara, politik uang, dan proses pemungutan saat hari pencoblosan.

Dalam konteks ini, tantangan utama yang dihadapi adalah keterbatasan jaringan sehingga dalam penghitungan suara, Sirekap belum maksimal dalam mengumpulkan data hasil dari setiap TPS.

Keempat, hambatan cuaca. Pelaksanaan pilkada di bulan Desember dengan kondisi musim hujan berpotensi mengganggu tahapan pemilihan khususnya pada pengamanan perlengkapan pemungutan suara, distribusi logistik, dan proses pemungutan suara. Potensi adanya hujan, angin kencang, dan ombak akhirnya dialami oleh sebagian daerah yang melaksanakan Pilkada 2020. Hal itu berakibat pada distribusi logistik yang terlambat sebagaimana hasil pengawasan Bawaslu yang pada akhirnya memundurkan waktu pembukaan TPS.

Selain itu, akibat kondisi alam, terdapat TPS yang akhirnya dipindah karena lokasi sebelumnya terkena banjir sehingga pemungutan dan penghitungan suara tidak dapat dilakukan di lokasi tersebut. Kondisi alam yang dapat mengganggu pelaksanaan pemungutan dan penghitungan suara wajib menjadi perhatian bagi penyelenggara pemilihan ke depan.

\section{Pilkada Desember 2020; Kehendak Elite atau Rakyat?}

Penundaan (pergeseran) Pilkada dari September ke Desember 2020 memicu reaksi sebagian kalangan karena pilkada dilaksanakan di tengah situasi pandemi covid-19 yang melanda Indonesia. Berbagai elemen civil society seperti Nahdhatul Ulama dan Muhammadiyah secara resmi meminta agar pilkada di tunda. Begitu juga dengan kalangan non government organization yang selama ini fokus terhadap isu-isu pemilu, mayoritas menolak pilkada pada Desember 2020. Argumentasi utamanya adalah bahwa pelaksanaan pilkada di tengah pandemi, hanya akan menambah persoalan baru karena pilkada berpotensi menjadi sumber penyeberaan baru virus covid-19.

Jika dikaji secara mendalam, pelaksanaan pilkada (pemungutan suara) pada 9 Desember 2020 sebenarnya lebih merefleksikan kehendak kepentingan elite dari pada kepentingan publik secara luas. Setidaknya ada dua hal yang mendasarinya. Pertama, dalam perspektif elite, pilkada harus dibaca dalam konteks "arus kas masuk". Semua partai politik berpotensi besar mendapatkan logistik dari para kandidat kepala daerah sebagaimana yang lazim terjadi selama ini. Dengan kata lain, potensi uang masuk ke kantong-kantong partai (elite) politik menjadi hilang atau tertunda jika pilkada diundur terlalu lama. 
Momentum emas ini tentu tidak boleh "dihilangkan" begitu saja mengingat partai politik dituntut untuk dapat mengelola sumber-sumber pendapatan strategis.

Kedua, para kandidat kepala daerah yang sudah memulai proses sejak tahapan awal pilkada, dihadapkan pada situasi dilematis. Sebagian besar kandidat tentu sudah menghabiskan logistik yang tidak sedikit dalam proses awal kandidasi, baik kandidat yang menggunakan pintu parpol maupun pintu perseorangan. Jika pilkada ditunda dalam jangka waktu yang cukup lama, tentu beban (logistik) kandidat akan bertambah ekstra terutama dalam konteks menjaring dan "menjaga" kantongkantong suara yang potensial berubah. Menjaga suara bukanlah pekerjaan mudah karena mengharuskan para kandidat (bakal calon kepala daerah) untuk menambah cadangan logistik selama momentum jeda tersebut.

Keputusan penyelenggaraan pilkada 9 Desember 2020 secara politik memang mengandung pesan optimisme dari stakeholders untuk bersatu melawan covid. Namun demikian, ruang-ruang pesimisme publik masih tetap menggelayuti mengingat kendala-kendala berat yang akan dihadapi.

\section{Pilkada di Era Pandemi Membentuk Standar Cost Politik}

Lumpuhnya aktifitas perekonomian terutama di daerah-daerah zona merah covid-19, melahirkan kantong-kantong kemiskinan baru. Problem utama yang dihadapi masyarakat tentu saja adalah menurunnya daya beli yang berimbas pada ketidakmampuan dalam menyediakan pasokan logistik (pangan) untuk rumah tangga mereka. Respon pemerintah atas problem krusial ini secara eksplisit ditunjukkan dengan program jaring pengaman sosial, salah satunya adalah bansos pangan (sembako). Insentif bahan pangan pokok ini dianggap dapat mengurangi langsung beban pengeluaran masyarakat miskin.

Dalam situasi darurat, model bansos sembako menjadi semakin populis dan menjadi role model program unggulan para kandidat kepala daerah untuk menjaring suara. Pada titik inilah, politik transaksional menjadi semakin terbuka. Politik uang lagilagi menghantui proses sirkulasi kepemimpinan lokal di tengah pandemi.

Jika pada situasi normal, politik uang dianggap sebagai suatu "kelaziman", maka pada era pandemi di mana pilkada diselenggarakan di tengah situasi covid-19 (bencana non-alam), politik uang semakin mengukuhkan kelaziman praktek electoral tercela tersebut. Dalam perspektif sosiologi politik, money politic dapat dipahami sebagai wujud sistem pertukaran sosial yang biasa terjadi dalam realitas permainan politik. Interaksi politik meniscayakan adanya penggarapan timbal balik (reciprocity). Dengan kata lain, relasi resiprositas merupakan dasar bagi terciptanya sistem pertukaran sosial yang seimbang.

Di sisi lain, massifnya program stimulus pangan (sembako) secara alamiah akan membentuk standar cost politik tersendiri. Standar cost dalam konteks ini merujuk pada kemampuan para kandidat yang distandarisasi dengan kemampuan mereka memberikan garansi material bagi praktek vote buying.

Yang patut dikhawatirkan adalah ketika situasi wabah ini justru dijadikan "legitimasi" bagi praktek politik transaksional karena dibangun di ataz azas "kepentingan bersama". Para calon kepala daerah dengan mudah akan beralasan bahwa tidak ada program lain yang dianggap efektif kecuali politik uang (uang/barang). Politik uang dianggap sebagai kelaziman karena masyarakat pemilih membutuhkannya. Sementara itu, bagi pemilih, pilkada adalah momentum paling tepat untuk "menguji" sejauhmana kemampuan dan keseriusan calon kepala daerah. Inilah tantangan berat sekaligus pertaruhan bagi pelaksanaan pilkada yang sehat dan jurdil.

Pilkada di tengah pandemi pada akhirnya melahirkan arena baru money politic yang berpotensi dilakukan secara terangterangan meskipun melanggar UU karena menjadi bagian dari tindakan pidana pemilu. Pertanyaannya adalah, apakah perangkat Badan Pengawas Pemilu siap untuk melakukan tindakan jika program ini pada akhirnya dianggap sebagai suatu 
kelaziman tersendiri di tengah pandemi yang belum selesai?.

Secara teoritis, salah satu faktor penting yang berkontribusi terhadap praktek politik uang adalah desain institusi politik (van de Walle, 2007). Pilkada sebagai mekanisme demokrasi langsung jelas melibatkan pemilih secara langsung sehingga membuka ruang-ruang transaksional dengan kandidat. Calon pemilih terutama yang berstatus sebagai swing voters, adalah lahan empuk bagi alokasi-alokasi dan distribusi material sebagai manifestasi dari praktek vote buying yang dilakukan kandidat.

Sebagai pembanding, proporsi pemilih yang terlibat politik uang dalam pemilihan terakhir (Pemilu 2019) berada di kisaran 19,4\% hingga 33,1\%. Kisaran politik uang ini sangat tinggi menurut standar internasional, dan menempatkan Indonesia sebagai negara dengan peringkat politik uang terbesar nomor tiga di dunia. Politik uang telah menjadi praktik normal baru dalam pemilihan umum (Muhtadi; 2019).

\section{Tantangan Peningkatan Literasi Elektoral dengan Pemanfaatan ICT \\ Dalam era "normal baru",} pemanfaaatan information communication technology (ICT) untuk meningkatkan literasi electoral menjadi sangat mendesak, tidak hanya bagi KPU tetapi juga bagi para kandidat kepala daerah. Digital habbit perlu dioptimalkan untuk menjaga kualitas pilkada.

Bagi KPU, beberapa tahapan pemilihan mestinya dapat dimaksimalkan dengan menggunakan perangkat ICT sebagai bentuk adaptasi atas kondisi yang sedang terjadi. Pemutakhiran daftar pemilih misalnya, dapat dilakukan berbasis internet dengan menggunakan aplikasi ecoklit. Verifikasi faktual bakal calon perseorangan, dapat memaksimalkan penggunaan conference technology untuk mengimbangi praktek sensus konvensional. Selain itu, pendidikan pemilih mestinya juga dapat dilakukan berbasiskan internet untuk meningkatkan digital engagement pemilih dan memperkuat network society yang cerdas terhadap literasiliterasi electoral.

Bagi kandidat kepala daerah, pilkada di tengah pandemi menuntut kreatifitas dalam berburu suara. Karena keharusan mengikuti protocol covid, model-model kampanye tatap muka sebagaimana yang lazim terjadi pada era normal, tentu memiliki keterbatasan. Model kampanye tatap muka, pertemuan terbatas, dialog mensyaratkan adanya mobilisasi massa sehingga menimbulkan pusat-pusat kerumunan yang berpotensi menjadi cluster baru penyebaran virus.

Sementara itu, menjaring suara secara virtual, juga bukan pekerjaan mudah karena keterbatasan perangkat infrastruktur teknologi informasi yang tersedia dan rendahnya tingkat literasi internet di sejumlah daerah.

KPU memang telah mengatur penggunaan alat digital pemilihan pada masa pandemi Covid-19, yakni media daring, media pertemuan secara daring, dan multiplatform. Media daring diperlukan sebagai sarana penyebarluasan informasi, pertemuan dan rapat, sosialisasi, dan periklanan dengan memanfaatkan internet. Sementara itu aplikasi daring, seperti Zoom, Google Meeting, dan lainlain dapat dimanfaatkan untuk menggelar pertemuan atau rapat-rapat. Adapun multiplaform merupakan kombinasi sejumlah aplikasi maupun platform untuk keperluan sosialisasi dan kampanye. Namun demikian, penggunaan perangkat teknologi informasi tersebut tampak belum optimal.

Virtual campaign seperti penggunaan perangkat Zoom, Google Meet dan aplikasi-aplikasi daring lainnya hanya diikuti oleh kelas menengah ke atas yang sudah familiar dengan perangkat-perangkat teknologi virtual tersebut. Sementara itu, mengandalkan social media sepeti facebook, twitter, instagram, dan lain-lain juga dihadapkan pada keterbatasan tersendiri karena sejauh ini, efektifitasnya tidak terlalu signifikan sebagai model kampanye, dibanding proram-program kampanye tatap muka secara langsung. Dengan kata lain, menyandarkan pada program 
kampanye daring an sich, tidak sepenuhnya optimal dalam menjaring suara pemilih.

\section{Jaminan Kesehatan dan Proteksi Hak Pilih}

Selain politik uang, kampanye, dan dukungan anggaran, jaminan kesehatan dan perlindungan hak pilih juga menjadi masalah krusial dalam pilkada di tengah pandemi. Jaminan kesehatan menjadi elemen penting pelaksanaan pilkada, tidak hanya bagi penyelenggara pemilihan tetapi juga pemilih. Protocol kesehatan terutama pada saat vote day (pemungutan dan penghitungan suara) harus benar-benar diimplementasikan dengan kontrol ketat. Tindakan perlindungan di tempat (protection measures in place) perlu dipertimbangkan sebagai bentuk jaminan kesehatan bagi pemilih.

KPU mestinya memastikan seluruh warga negara dapat menggunakan hak pilihnya termasuk pemilih yang sedang menjalani karantina wajib (mandatory quarantine) secara optimal. Pemilih yang masuk dalam kategori Orang Dalam Pengawasan (ODP), maupun Pasien Dalam Pengawasan (PDP), meskipun tidak dapat menggunakan hak pilihnya di TPS, namun tetap harus dilindungi hak pilihnya dengan pelayanan khusus oleh KPPS bersama Pengawas dan Saksi bekerjasama dengan Tim Kesehatan atau Gugus Tugas Percepatan Penanganan Covid-19. Perlindungan hak pilih ini menjadi penting untuk memastikan kualitas penyelenggaraan pilkada.

\section{Kesimpulan}

Meskipun banyak tantangan, proses rekonsolidasi demokrasi lokal harus tetap berjalan sebagai konsekuensi atas keputusan politik bersama yang telah diambil. Ekspektasi publik atas pilkada yang berkualitas di tengah pandemi harus ditafsirkan sebagai energi positif bagi terwujudnya tata kelola pemilihan yang sehat dan jurdil.

Dari perspektif demokrasi prosedural, pilkada langsung jelas merupakan kemajuan demokrasi yang layak diberikan apresiasi. Hanya saja, format pilkada yang disepakati antara pemerintah dan DPR menyimpan pelbagai persoalan krusial, baik dari sisi substansi pilkada langsung, distorsi kewenangan dan regulasi, tumpang tindih kelembagaan dan problem legitimasi.

Ekspektasi publik terhadap munculnya kepemimpinan daerah yang berkualitas dan bertanggungjawab, belum tentu bisa terealisasi. Sebab, demokrasi substansial juga ditentukan oleh variabel kinerja dan akuntabilitas para elite yang terpilih.

Selama lima kali pergantian model pemilihan kepala daerah, basis legal penyelenggaraan pilkada dapat dikatakan belum memiliki kapasitas adaptif terhadap situasi yang terjadi seperti situasi bencana non alam (pandemi covid). Hal inilah yang menjadi catatan penting khususnya bagi pembentuk Undang-Undang (DPR dan Pemerintah) agar bisa menyiapkan perangkat hukum yang lebih adaptable untuk menghasilkan pilkada yang berkualitas dan demokratis.

\section{Saran}

Saran yang dapat diberikan adalah sebagai berikut:

1. DPR yang memiliki fungsi legislasi diharapkan dapat lebih responsif lagi dalam menyusun peraturan perundang-undangan yang memadai tentang pemilihan umum kepala daerah. Basis legal peraturan pilkada harus memiliki visi yang jauh ke depan dan menyediakan ruang yang cukup untuk mengantisipasi segala kemungkinan yang terjadi khususnya kejadian-kejadian bencana non alam.

2. Meskipun secara umum pelaksanaan pilkada serentak 2020 di tengah pandemi berjalan aman dan terkendali, namun berbagai temuan lapangan yang muncul harus ditindaklanjuti oleh stakeholders terkait baik dari sisi penyelenggara pemilu, pemerintah, DPR RI dan seluruh elemen civil society untuk menciptakan pilkada yang sehat dan berkualitas. 


\section{DAFTAR PUSTAKA}

Armitage, D. R., \& Plummer, R. (Eds.). (2010). Adaptive Capacity And Environmental Governance. Berlin, Germany: Springer

Keputusan Presiden No 12 Tahun 2020

Tentang Penetapan Bencana Non Alam Penyebaran Corona Virus Desease 2019 (Covide-19) Sebagai Bencana Nasional.

Pelling, M., \& High, C. (2005). "Understanding adaptation: What Can Social Capital Offer Assessments of Adaptive Capacity?”. Global Environmental Change 15(4):308-319. doi:10.1016/j. gloenvcha.2005.02.001

Peraturan Komisi Pemilihan Umum Republik Indonesia Nomor 6 Tahun 2020 Tentang Pelaksanaan Pemilihan Gubernur Dan Wakil Gubernur, Bupati Dan Wakil Bupati, Dan/Atau Wali Kota Dan Wakil Wali Kota Serentak Lanjutan Dalam Kondisi Bencana Nonalam Corona Virus Disease 2019 (Covid19)

Retno Saraswati, 2011, Calon Perseorangan: Pergeseran Paradigma Kekuasaan dalam Pemilu, Jurnal Masalah-Masalah Hukum, Vol.4 No.2, diakses 12 Agustus 2021 dari https://ejournal.undip.ac.id/index. $\mathrm{php} / \mathrm{mmh} /$ article/view/10470/83 46

Sekretariat Bersama Kodifikasi Undangundang Pemilu, 2017. Pemilihan Kepala Daerah Adalah Pemilu, Policy Brief (03) Kodifikasi Undang-undang Pemilu
Smit, B., \& Wandel, J. (2006). “Adaptation, Adaptive Capacity and Vulnerability". Global Environmental Change 16(3): 282292.

doi:10.1016/j.gloenvcha.2006.03.00 8

UU Nomor 1 Tahun 2015 Tentang Penetapan Peraturan Pemerintah Pengganti Undang-Undang Nomor 1 Tahun 2014 Tentang Pemilihan Gubernur, Bupati, dan Walikota Menjadi Undang-Undang

UU Nomor 8 Tahun 2015 Tentang Perubahan Atas Undang-Undang Nomor 1 Tahun 2015 Tentang Penetapan Peraturan Pemerintah Pengganti Undang-Undang Nomor 1 Tahun 2014 Tentang Pemilihan Gubernur, Bupati, dan Walikota Menjadi Undang-Undang

UU Nomor 10 Tahun 2016 Tentang Perubahan Kedua Atas UndangUndang Nomor 1 Tahun 2015 Tentang Penetapan Peraturan Pemerintah Pengganti UndangUndang Nomor 1 Tahun 2014 Tentang Pemilihan Gubernur, Bupati, dan Walikota Menjadi Undang-Undang

UU Nomor 6 Tahun 2020 Tentang Penetapan Peraturan Pemerintah Pengganti Undang-Undang Nomor 2 Tahun 2020 tentang Perubahan Ketiga atas Undang-Undang Nomor 1 Tahun 2015 tentang Penetapan Peraturan Pemerintah Pengganti Undang-Undang Nomor 1 Tahun 2014 tentang Pemilihan Gubernur, Bupati, dan Walikota Menjadi Undang-Undang Menjadi Undang-Undang 